\title{
Why have scientists accepted Zuckerman's opinion that no human oogenesis after birth?
}

\section{The origin of the problem}

Since Zuckerman proposal ${ }^{1}$ in which he reported that female women has a fixed number of oocytes in her fetal life and stop producing oocytes after born. ${ }^{1}$ This longstanding (dogma) by Zuckerman had arrested a created think and losing decades of research (60 years) based on this misleading finding and wrong proposal. So, the direction in studying this matter in embryology was absent because the most of the scientists had accepted this supposition and all their previous researches agreed and emphasized that females are born with all the egg cells she will ever have in her life time. In the current decade the hot debate was starting discussing this issue.

\section{The recent opinions}

Currently, ${ }^{2}$ criticized that old dogma of non-production of oocytes after birth. He suggested that Stem cells were found in embryo and certain adult body tissues having the potential to grow into different types of cell. He wrote: (stem cells go right into your blood supply and go right to your ovaries resulting in production of new oocytes). ${ }^{2}$ This assumption led to another hot debate. David Albertini calls such claim outrageous and a frank travesty that has falsely raised the hopes of many women. Woods et al., ${ }^{3}$ noted that there are still no evidence that the oogonia stem cells form new eggs naturally in the body and other criticized this assumption too.

\section{What is written about Oogenesis}

The embryological textbooks (based on old doctrine) had mentioned that the females in their fetal life having about two millions of primary oocytes in their ovaries. ${ }^{4}$ Most regress during their childhood so that by adolescence only about 40,000 cells remain, of these only approximately 400 become secondary oocytes and are expelled at ovulation during reproductive period. ${ }^{4}$

\section{Opinion and comments of the author}

Fortunately Zuckerman had admitted that he did not offer a single experiment proving that adult female mammals are incapable of oogenesis. This gives us the right to criticize and speculate his old opinion. Previous studies have reported a number of results most of them are for Zuckerman's proposal and a few were against it. Why is there a controversy about stem cell producing oocytes (Tilly) and about non production of oocytes after birth (Zuckerman). The author thinks that the strongest evidences indicating that the previous proposals were unsuccessful, unconvincing and illogical are:

1. It was illogical supposition (belief) of Zuckerman that there is no oocytes production after birth because this interpretation against dynamic of life and development of human being. The growth and division of cells are the main features of all organisms including humans. The continuing production of new oocytes is one these human features. The author asks the biologists: how could cells (oocytes) be created, divided and developed at the beginning of fetal life and stop division
Volume 4 Issue 3 - 2017

\author{
Othman Salim Hussein Al-Fleesy \\ Department of Forensic Medicine and Pathology, Aden \\ University, South Yemen
}

Correspondence: Othman Salim Hussein Al-Fleesy,Associate Professor of Forensic Medicine, Department of Forensic Medicine and Pathology, Faculty of Medicine and Health Sciences, Aden University, Aden, South Yemen, Emailalfleesy200I@yahoo.com

Received: March 18, 2017| Published: March 31, 2017

or production suddenly at the seventh month of fetal life and continuing this stoppage after birth while every cell in the body is continuing division, growth in the race of development? So, if this proposal of Zuckerman is true (which is not so) Logically the age of primary oocytes and in depth - after birth- must be the same and static as in fetal life (not more than 7 months) because there is no production after birth and they stay dormant and latent as biologists stated in their textbooks. how can these primary oocytes remain dormant-after birth- for years of life with the same static age (7 months), and then they may wake up after more than ten years, and a number of them (group) (121000 primary oocytes) begin the process of division and one only ovulated, while others (40000--700000) still dormant.

2. Illogical total number of oocytes and a big mistake in estimating and calculating these oocytes. Some embryologists wrote one million and others said it reached seven millions. This huge, wrong number leading to mistrusted results.

3. Unsuccessful explanation of embryologists for the primary oocytes division at puberty period and the beginning of monthly ovarian cycle. They stated that after birth and at puberty the Primary oocytes after their dormant and suspended prophase they completed their division and before ovulation (36-48) hours the secondary oocytes enter to metaphase stage and arrested to be completed after fertilization. And they had related this long dormant to occurrence of chromosome 21 disorder (trisomy21) and down syndrome. How could we say that at puberty the ovum matured and ovulates, but we did not remember what happened during these years (infancy - puberty)? Because these ova are not growing and maturing suddenly, but they have entered the process of development and growth since fertilization (with all stages) till maturity. The process of mitosis continues until we were born, and continues until we were grown up. No one knows when do cells stop growing. Nobody knows exactly how much you will grow. And what causes the human body to grow.

4. Growth is a fundamental characteristic of humans. It is Unequivocal that cells have programmed by The creator (The 
God), and the growth is going in different stages (phases), from zygote, Neonate, infant, up to full maturity. Every stage (period) has its own requirements and time (age). J. Overbeck defined time as: The Great gift of nature which prevents the occurrence of everything at once. But in fact the time is the gift of the creator, (the GOD). Also, (an arrow of time) is a term released by a famous British physician in 1928, he stated: time has one direction. ${ }^{5}$ All living humankind is the result of the movement of time which is estimated by time scaling (hours, days, months and years). Nothing happens outside time except the God miracle of cavemen. Allah says: (So We cast [a cover of sleep] over their ears within the cave for a number of years. ${ }^{6}$ And Allah says: (And they remained in their cave for three hundred years and exceeded by nine. ${ }^{7}$ Everything on the earth's surface has a time's brand (obvious or hidden).

5. Again, It is clear that there is a jump on the time (period, age), when the scientists stated that the oocytes after birth remain in dormant or suspended status till the puberty or menopausal age. How could these cell be out of time with no growth?

In human body, the growth includes all the organs, tissues and cells. Please look to these samples and examples of growth whatever the function of organ is:

a) The thymus glands start development in infancy and childhood. After puberty it starts to slowly shrink and become replaced by fat.

b) The growth of the bone (faster), starting by ossification centers (fetal life and to ending in full maturity). The growth of the teeth starting with milk teeth in infancy and ending with the last one wisdom teeth(third molar) of the permanent teeth

c) The disappearance of RBCs nuclei after their maturity.

The growth and division of cells are important of almost all organism including humans. Naturally Ovaries are continually producing new eggs as the organ has this ability to producing. Who is able (from scientists) to prove that there is no division, no growth, and no production after birth. It was a false claim by Tilly and others when they concluded that stem cells are coming from bone marrow or peripheral blood to locate in this site (ovary) and to produce new oocytes or to replenish or to generate them. Which raised a controversial more than Zuckerman proposal? Stem cells that come from bone marrow or blood(if this is true and proved because scientists still in doubt), may have other tasks or missions in the body elsewhere still not discovered by biologists, but not to generate or produce oocytes, because oocytes have another well-equipped factory (the ovary).

\section{Conclusion}

After reviewing these proposals the author concluded:

1) There is a continual production of new oocytes till the decline of normal physiology of the human female body. The continual production of oocytes is still of unknown origin to researchers but definitely there is programmed self-creating and production of these new egg cells from ovaries - but not stem cells -never mentioned before.

2) The human body has an integral and complex physiology, so the previous false proposal (non-production of oocytes after birth), reflected itself in studies and results of scientists and their misinterpretation in giving terms and words which did not represent the main concept such as: dormant primary oocytes, suspended prophase, at retic oocytes in fetal ovaries.....etc.

3) The egg cells (oocytes) created and produced in their ovaries. It is the only factory for this production. The factory of airplanes never produced cars.

4) Unability to (observing) the continuity of creation and growth of new egg cells by either due to our lack of knowledge or deficiency in technology: the available tools, devices, equipments..etc; does not consider an evidence against the presence and production of egg cells in ovaries. Because it may be a secret and mystery of God Allah says: (I did not make them witness to the creation of the heavens and the earth or to the creation of themselves, and I would not have taken the mis guiders as assistants. ${ }^{8}$

5) The scientists must -whatever their science and knowledge they have- remember always that the human being is created by the creator who gave you this science, and life and to remember too that the universe including the humans is controlled by the God, So if you do not believe this, please push and stop death by your science and technology. Allah says: (They ask thee concerning the Spirit (of inspiration). Say: "The Spirit (cometh) by command of my Lord: of knowledge it is only a little that is communicated to you. ${ }^{9}$

Finally, on the basis of previous comments, the author calls all scientists in this field to revise again the process of spermatogenesis.

\section{Acknowledgments}

None.

\section{Conflicts of interest}

None.

\section{References}

1. Zuckerman S. The number of oocytes in the mature ovary. Recent Prog Horm Res. 1951;6:63-108.

2. Johnson J, Canning J, Kaneko T, et al. Germline stem cells and follicular renewal in the postnatal mammalian ovary. Nature. 2004;428(6979):145150.

3. Woods DC, Telfer EE, Tilly JL. Oocyte Family Trees: Old Branches or New Stems? PLOS Genet. 2012;8(7):1002848.

4. Langman. Medical embryology. TW Sadler. 13th edn. Clinical Medicine. 2015 .

5. Zawail A. Time's mysteries and meracles. Bibliotheca Alexandrin, Egypt, $2005 ; 1-86$

6. Qur'an H, Surah: Al-kahf (The Cave) verse11.

7. Qur'an H, Surah: Al-kahf (The Cave) verse25.

8. Qur'an H, Surah: Al-kahf (The Cave) verse 51.

9. Qur'an H, Surah: Al- Israa, Verse85. 